\title{
ANIMAL SOUNDS: A HUMAN VANTAGE POINT
}

\author{
EKATERINA RAKHILINA \\ Russian State University for the Humanities \\ [Translated from Russian by Irena Marijanovićc]
}

\section{A B S T R ACT}

Why is it that the lexicon is often shunned and ignored by linguists, or in other words, treated with disdain and generally considered to be the Ugly Duckling of the linguistic family? This paper is both an attempt to redress the balance and it is designed as a tentative, initial contribution to the study of verbs of sound. Here, the central focus is devoted to a small subsection of verbs of sound, namely to the verbs denoting animal sounds used with metaphorical reference to human beings. The paper also attempts to sketch possible situations and parameters which are relevant for human beings and which appear to be cross-linguistic universals. The discussion is for the most part focused on Russian but examples from other languages, such as English, German, Estonian, and so forth, are also included.

\section{[1] INTRODUCTION}

There is a tradition according to which language is believed to be grammar and not the lexicon. This tradition has been upheld in linguistics for centuries, and for understandable reasons. It is curious, however, that this way of thinking about language is present in some fashion in the minds of "ordinary" native speakers. Indeed, when someone who is learning a foreign language says: "I seem to have picked a rather hard (or easy) language to learn", what one has in mind is that the inflectional system or the conjugational patterns of the language in question are complex. And not the fact that one has to learn a rather large, or conversely, a rather small number of words in order to speak freely: this aspect is not understood as an integral part of the language learning process. This situation can even be seen as enigmatic in some sense because one would believe that what the "ordinary" speakers and hearers say and hear are, in fact, words, that is, the very substance of language. But it is precisely the latter which is being ignored.

Strictly speaking, it is because of such a generally dismissive attitude towards the lexicon that we know so little about it. For instance, at the present time, we are unable to answer the question of whether a given language is simple or complex (or, in other words, whether it is poor or rich) when taking the lexical bulk as one's vantage point. Some linguists will argue that, generally, it makes no difference because all languages inherently have an equal wordage, compensating for 
any gaps in their lexicon in some other fashion. To be quite honest, before I got involved in comparative research on lexis, I was of the same opinion. However, in order to provide a more accurate assessment of this issue, further, more comprehensive studies are needed. Indeed, it would be foolish to directly compare the lexical items of different languages by consulting the relevant dictionary entries. Every dictionary adheres to its own principles: some pay close attention to polysemy, whereas others ignore it; some include derivational morphology and yet others even prepositional or adverbial collocations (of the type to go out) as separate entries. Since this problem cannot be resolved in a straightforward manner, we should refrain not only from hastily appraising the lexical bulk of a given language, but also the volume or weight of the semantic field, and only then can we compare the two.

In their time, the morphologists also encountered a similar problem, that of an incommensurability of grammatical descriptions. Then, at the beginning of the '70s, this became an impetus behind a rapid development of the theoretical and practical aspects in the field of grammatical typology (cf., for example, Kholodovič (1969), Comrie (1976), Dahl (1985) and others). Now it seems the time of lexical typology may have come. The initial steps in this direction have already been made. If we are to speak of the advances made in this field on the international scene, then first of all we need to mention the projects of MPI for Psycholinguistics at Nijmegen (Majid \& Bowerman (2007); Majid et al. (2008)), Cliff Goddard and Anna Wierzbicka (see, for instance, Goddard \& Wierzbicka (2002)), Åke Viberg (Viberg 2002) and John Newman (Newman 1997, 2002, 2009); for a more detailed overview of the field, see Koptjevskaja-Tamm et al. (2007) and Koptjevskaja-Tamm (2009). In Russia, on the other hand, there is a well established branch of "diachronic" typology (see Dybo (1996), Zaliznjak $(2001,2009))$ as well as synchronic research. With regard to the latter, we can mention an already completed research project on the "aquatic" verbs of motion Majsak (2007) and an ongoing project on the verbs of pain (Bonč-Osmolovskaja et al. (2009), Bricyn \& Rakhilina (2009)). However, this is but a beginning. There ought to be many more research projects of this kind, and to gain an insight into the general picture such projects should address different problems in the field of lexical linguistics.

The present paper is a small step towards a future project which, for the time being, remains my own private reverie: it will ultimately focus on the verbs of sound. This field is in itself highly interesting because it provides a very subtle denotative basis for comparing different languages. Indeed, there is almost a complete absence of a "video sequence", so to say, which determines the situation structure of the verbs of motion (see Majsak (2007)) or the verbs of deformation (see the project on cutting \& breaking). Strictly speaking, such verbs are simply untranslatable from one language to another: how should šumet' ('to rustle') be distinguished from gudet' ('to drone') so that we can find the correct translation? 
One could assume that instead of the perceptual there is a common acoustic plane, but from a denotative point of view it is equally impossible to rely on sound as it is on perception: the sound of the forest and the sound of water are two entirely different sounds.

However, the world of sounds is extremely variegated (which implies that my imagined future project will be rather large). Indeed, there are sounds made by human beings (e.g. the Russian verb šarkat' ('to shuffle')) and those made by animals (e.g. ryčat' ('to bellow')); and then there are sounds produced by natural objects (e.g. žurčat' ('to murmur') and those by artefacts (e.g. ljazgat' ('to clank')), among which musical instruments represent a special class (e.g. brenčat'). It is also possible to establish further subclasses within each of these four classes (see the analysis in Stojnova (2008)).

Here we consider the most cheerful subclass of all, namely, animal sounds. It is a known fact that animal sounds are used metaphorically with reference to human beings. A question arises: just which human sounds are rendered as "animal", "avian" or "insect"? The simple answer to this question is: inarticulate sounds. In fact, sounds that animals make may be likened to human sounds only if they do not convey the information customarily associated with human speech, or if humans do not identify such sounds as essentially "animal". However, the classification of these sounds, and of their corresponding situations, is of much interest: the present paper addresses the development of one such classification system and discusses the examples of its "work" based on a small sample of typological material. The lexico-typological component of this work is an attempt to understand which sound situations are so cognitively relevant that special lexical markers assigned to them are found in the languages of the world. We also raise the issue of to what extent these markers are unique with regard to their semantics, that is, whether there are rules and regularities to be found in the process of metaphor selection, or whether every metaphor in every language is simply unique. It is clear that we can speak with greater certainty of the existence of lexical typology, even in this unprototypical lexical domain, the more rules and regularities we uncover.

It should be pointed out in advance that we managed to examine only a few languages and can therefore boast of only rudimentary findings. It seems to us, however, that they should be of a considerable linguistic interest in the view of the novelty of the field of lexical typology. We are dealing, first of all, with Russian material, as well as English, German, Norwegian, Italian, Armenian, Czech, Bulgarian, Hindi and Estonian. I am deeply grateful to all my colleagues who provided me with the necessary data from the languages they are familiar with: L. Janda, T. Nesset, V. Khuršudjan, T. I. Reznikova, L. V. Khokhlova, U. Sturop, A. Van'kaeva, D. Stanulevič, and E. Tančeva. 
[2] GENERAL CLASSIFICATION: A FRAGMENT.

[2.1] Non-verbal inarticulate sounds.

And so, we take as our starting point the fact that inarticulate sounds made by humans in many languages of the world may, as metaphors, come to resemble animal sounds. The corresponding situations can be divided, with a certain grain of conventionality, into non-verbal and verbal.

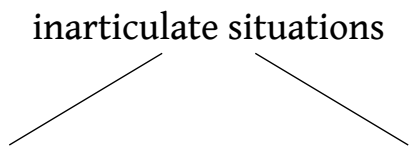
1. non-verbal
2. verbal

We start with the non-verbal sounds, which can further be uncontrollable and controllable. The non-verbal uncontrollable sounds can, in their turn, be divided into physiological sounds, which are engendered by bodily processes (e.g. Russ. krjakhtet' ('to groan'), čikhat' ('to sneeze'), khripet' ('to wheeze'), khrapet' ('to snore'), etc.), and the spontaneous (non-verbal) reactions to an external situation. The latter can either be negative, such as "crying", or positive, such as "laughter". With regard to the non-verbal controllable sounds, all kinds of muttering lacking a specific addressee may be considered to belong here, as well as wordless singing.

Therefore, the first of the two branches of our classification has the following appearance:

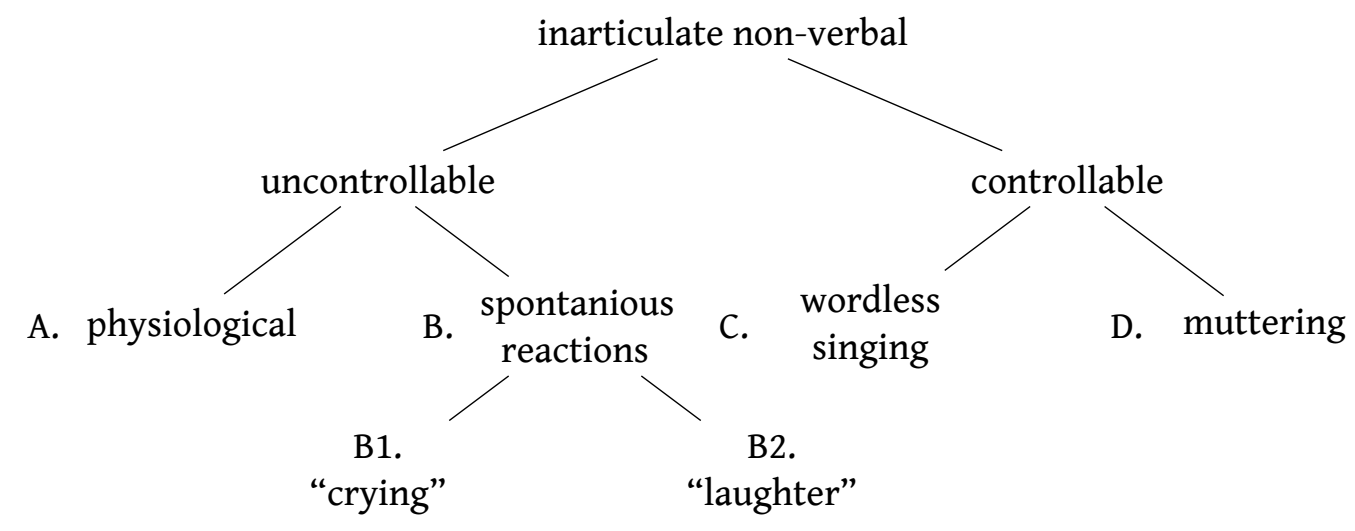

We shall systematically examine its terminal subclasses with regard to animal metaphors in the world languages.

A. "Physiological sounds"

As already mentioned, we have in mind the spontaneous bodily reactions which are somehow or other accompanied by sounds. This takes place precisely when 
one's stomach starts "making sounds" independently of one's volition, for example, after a meal. Such a situation stands out and is almost always rendered by an animal metaphor. It is as if there were a wild animal in one's stomach, usually a dog or a bear, as in Russ. určat' ('to growl') or Eng. growl (of a dog and a bear). Next, we turn our attention to this unique contamination of a dog and a "good" bear, which we revisit once more later in the paper. We also observe that no reference is made to a wolf although in principle, as we shall see later, a dog may be easily mixed with a wolf in other cases.

Pigs, as a source of metaphors, play the most significant role in this set of situations. It is a question of a characteristic wheezing (grunting) sound which by virtue of its phonetic quality is easily likened to various physiological processes: in Armenian, the sound will be interpreted as 'to emit a death rattle'; in Estonian as belching; in Kalmuck as snoring; in Bulgarian as groaning (including groaning from pleasure). A regrettable exception is Russian in which all above mentioned situations (snoring, groaning, and so on) are lexicalised, that is, each situation is expressed by its own verb, but not with the help of a zoological metaphor. Furthermore, the verb khrjukat' ('to grunt') does not have a stable, conventional context in which it could be applied to humans.

A curious situation obtains in Czech in which the corresponding verb is hrochtat and, like in Bulgarian, it is interpreted as groaning, in particular when one is lifting something heavy. However, the same verb can be translated into other languages not only as 'to grunt (of a pig)' but also as 'to hippo' (something in the vein of 'to make hippo-like sounds') because in Czech the word for hippopotamus itself (hroch) is directly associated with that sound. ${ }^{1}$

Another important source for the physiological domain are the cries of "clamorous" and "shrill" birds, above all the sounds produced by geese and crows. However, they only imitate the catarrhal voice in our sample (Bulg. grača 'hoarse voice' - lit. of geese and crows; Est. kraaksuma 'hoarse voice after having recovered from a cold' - lit. of crows).

As we can see, the whole physiological domain represents onomatopoeic sounds in their pure form: the metaphor's donor domain is chosen on the basis of a sound as such without any recourse to animal imagery. Precisely because of that the borrowing domain is very homogeneous and is replicated from language to language. In addition, the range of resulting recipient meanings itself is not very wide, although here one may expect the unexpected, for instance 'death rattle' as in Armenian, or 'belching' as in Estonian.

[1] This latter circumstance compels us to think about the possible lexical amalgamations of animal names and/or their sounds in the world languages. Even a most preliminary investigation reveals a high frequency of amalgamation of croaking (frog) and quacking (duck), especially in Norwegian, Czech, Estonian and other languages. An amalgamation of sounds produced by animal young is also possible. So, according to the data provided by our expert in Kalmuck, snoring is likened to the grunting of a piglet (not of a fully grown adult pig) which, in its turn, is amalgamated with the purring of kittens. 


\section{B. Spontaneous reactions}

As already mentioned, spontaneous reactions can be both positive (see Section B2) and negative (see Section B1), and certainly with regard to language as a whole, the domain of negative assessment is developed more thoroughly than the positive, although the negative and the positive assessments may be amalgamated from time to time (see Section B3). For the moment, however, we are only talking about the non-verbal human reactions in this segment of our classification system, that is, about those reactions which are not accompanied by words. This means that we are dealing with what could conditionally be named "crying" and "laughter", and the varieties of these. We start the discussion with "crying".

\section{B1. "Crying"}

That "crying" is a variegated phenomenon is already adequately demonstrated by Russian - the different kinds of "crying" are so significant for humans that they are lexicalised in different ways. In Russian, there are at least four different zoological "crying" metaphors, each with its own specific meaning: revet' ('to roar') (lit. pertaining to a large, predatory animal, prototypically to a bear, but also a lion, tiger, etc. but not to a wolf or, for that matter, a fox); vyt' ('to howl') (of a wolf or a dog); skulit' ('to whine') (of a wolf and a dog), and pišchat' ('to peep') (of chicks and mice - the two are not separated in Russian). It is quite obvious that like the whole domain of the zoological metaphor, and in particular those metaphors included in the negative domain, all these meanings are either coarse or very vulgar. In spite of this, such metaphors have a sufficiently wide usage. So, revet' is used with reference to children, denoting a very loud crying accompanied by tears, which does not refer to infants. It is the verb piščat' that is used to describe "infant crying". A man cannot revet' in that sense - when referring to a male person, this verb denotes a very loud and aggressive voice, that is, a verbal reaction (cf. with a more characteristic verb vzrevet' ('to give a roar')). In principle, an adult female cannot revet' unless she is consciously likened to a child. Vyt' (cf. also the inceptive verb vzvyt' ('to give a wail')) means to cry from an intense pain without tears and it resembles a wolf's cry. The other characteristic context for vyt' is the female keening over the body of a deceased (also without tears). Skulit' differs from vyt' with regard to both the intensity of the sound and original meaning: a fully grown wild animal can howl ( $\left.v y t^{\prime}\right)$ out of loneliness, it is said, as for instance a wolf howls at the moon, but a whelp whines (skulit'). In addition, whining is associated with making a request. For example, a dog whines at the table to persuade his owners into sharing some of their food with it. Because of that the Russian verb skulit' is more "inoffensive" than vyt' and is associated with a plaintive as well as suppliant crying.

In principle, a very similar situation obtains in other languages we examined: it focuses above all on wolves and dogs. Armenian is of an indisputable interest 
here, in which mooing is included in the same group. As we shall see, bovine mooing is associated with another verbal recipient domain, and the unexpectedness of its occurrence compelled us to scrutinise the Russian material more attentively. And here we stumbled upon a discovery: in Russian, the range of sources for the verb revet', comprising a set of large predatory animals, includes not only bears but also bulls that, unlike cows, do not myčat' ('to moo') but they do revet'. However, if we were to assume that the sounds made by bulls and cows, that is bellowing and mooing respectively ${ }^{2}$, can be amalgamated in a given language, then the case observed in Armenian becomes better motivated.

\section{B2. "Laughter"}

Here, the source of the zoological metaphor in Russian appears to be horses (ržat' ('to neigh')) and geese (gogotat' ('to gaggle')). Both of these verbs denote a very loud and raucous laughter, in the latter case the laughter is more "discreet" with regard to sound, as is the sound of the source. A close juxtaposition between a "homogeneous" and more "staccato" laughter is encountered in Armenian: between 'chirr' (of grasshoppers) and 'bleat' (of sheep) respectively. In English, the source of a metaphor for loud laughter is the owl (cf. the verb to hoot and also the expression that was a real hoot meaning 'it was very funny'). With regard to geese, their characteristic cry is used differently in English. It forms a zoomorphic metaphor in the artefactual domain: the English verb to honk imitates the sound of a car horn and is translated into Russian as "bibikat". A separate problem, of course, presents the question of artefacts as the sources of sound. Presently, it is not possible to delve deeper into this topic but the very fact that this field is structured in quite an interesting way, something which we shall encounter later on, and is easily captured by the zoological metaphor is very significant.

\section{B3. "Crying"/"Laughter" (mixed reactions)}

We should bear in mind that the positive and negative reactions cannot always be teased apart. It happens that both extremities are expressed by a single lexeme. An example of this kind is the Russian verb vizžat' ('to squeal both from pain and happiness'). It is true that this verb cannot be called zoomorphic in the full sense of the word because it does not juxtapose a human to an animal sound (here we have in mind the squealing of a pig), so strictly speaking, this is not the case of a

[2] The names of domestic animals are always fairly well distinguished lexically on the basis of sex, cf. Russ. kozel - koza ('billy-goat - nanny-goat'), baran - ovca ('ram - ewe'), kot - koška ('tomcat - cat'), etc. 
semantic shift. ${ }^{3}$ However, positive and negative reactions in metaphors are not contrasted in precisely the same manner, e.g. compare the English verb to howl (of wolves) meaning 'to cry or laugh very loudly' to the verb to roar, which carries approximately the same meaning and is in its literal meaning associated with lions, but not with bears or bulls as its corresponding Russian translation, revet', is. Incidentally, the Russian verb revet' also belongs to the class of mixed reactions, but only when it is used with a plural subject ${ }^{4}$ (cf. tolpa revela ('the crowd roared') may mean that the crowd is saluting the leader, or demanding his immediate resignation). We address the question concerning the role of the plural subject later in the paper.

Presently, we address the issue of non-verbal, uncontrollable sound situations as the recipients of zoological metaphors. In principle, it is not simple to distinguish the latter from the verbal ones precisely because humans have control over these sounds, which means that they utter them consciously. The basic parameter which could be used here to establish a more or less unambiguous border between the classes could be the presence or absence of an addressee. Indeed, prototypical speech is always addressed to someone; it fulfils a particular communicative task. The situations which we are presently examining preclude communication in the full sense of the word: here the acoustic substance, even if it contains words, is not addressed to anyone, with the possible exception of the speaker himself. However, even communication of this kind can be subdivided into distinct subclasses sufficiently connected with the world of animal sounds. These are "wordless singing" (C) and "conversation with oneself" (D); in addition, we have identified one more class (E) which may be tentatively called "singing without music".

\section{Wordless singing}

The situation in which wordless singing obtains is sufficiently significant in many languages. In Norwegian, for instance, there is a special underived verb, å nynne, which is used to describe it. In Russian, it is expressed by means of a metaphor, the "feline" verb murlykat' ('to purr'). It does not simply describe a cat's voice (cf. with the Russian verb mjaukat' ('to mew') which lacks such a meaning) but a

[3] On the other hand, the semantic shift is clearly discernable in the English equivalent of vizžat', namely to squeal. Here we have in mind the expression to squeal on smb which in its pure "human" sense means 'to turn informer; betray an accomplice or secret'. We observe that in Russian the same meaning may be rendered by an acoustic metaphor: stučat' na kogo-l.(lit., 'to knock on smb.'). However, in Russian, this mapping is realised not through the domain of animal sounds, but through an entirely different causal domain, that of the verbs of sound. For this reason, the metaphorical imagery regarding denunciation differs in Russian and English. In English, it is a vociferous announcement delivered in a particularly unpleasant tone of voice, as a shriek, of the type: "Mar' Ivanna, Petrov opjat' na uroke pljuetsja!" ("Mar Ivanna, Petrov is spitting again in the lesson!'). In Russian, on the other hand, it is a secret intimation, like rapping, cf. a different way of designating denunciation in Russian, namely, naušničestvo.

[4] On the behaviour of the singular subject see B1 
voice of a satisfied cat, which is semantically close to the canine/ursine verb určat' ('to growl') (see above). In other European languages, there is a more widespread link with the world of insects. In English, for instance, the verb to hum is used with that purpose in mind: it denotes a "quiet" buzzing that is characteristic of mosquitoes and flies but not bees (see below about the apian buzzing that is very often juxtaposed to that of mosquitoes). In particular, the verb to hum describes the manner, known to all, in which Winnie the Pooh sang his grumblings. This verb may be applicable to the act of singing with one's mouth closed, that is, completely without words. The German verb summen behaves in a very similar way; however, it extends to mosquitoes and bees. The French verb bourdonner, with the same meaning, describes the buzzing of flies, beetles, and humming birds.

\section{Conversation with oneself}

It is a known fact that this situation occupies an even more prominent place in the lives of humans than singing does. Humans, in particular although not exclusively old men, talk to themselves, and such a condition ought to have a name. In Russian, there is an underived onomatopoeic verb bormotat' ('to mutter'), but in many other languages this onomatopoeia is associated with low animal or avian sounds, like those made by a bear, as in German, or a chicken, as in English. It is interesting that the Norwegian cognate of the English verb to cluck, which is used in this situation, namely å klukke, has a more specific meaning: it does not simply mean 'to mutter to oneself' but 'to laugh quietly at oneself'.

\section{E. Singing without music}

A few more words about singing. Not only is wordless singing distinguished zoomorphically in many languages, but also "singing without music" that is off-key and unpleasant to the ear, that is, what in Russian is expressed by the collocation tjanut' kota za khvost ('to pull the cat by its tail'), cf. an example from the RNC (Russian National Corpus): 5

(1) Snizu igrali muzyku, khotja, kak vsegda, tjanuli kota za khvost (Asar Ėppel', Pomazannik i Vera 1990-2000)

'They were playing music downstairs although, as always, it sounded abysmally off-key' .

[5] Another meaning of this phrase is 'to hold back, detain', cf. also tjanut' rezinu ('to drag one's feet') or volynit' volynku ('to dawdle over smth') . Note also from the RNC:

(i) - Tak bystro? - A čego tyanut' kota za khvost. Raz-raz - i gotovo! - Čto ona delaet? Legla spat'? (V. P. Kataev, Dorogoj, milyj deduška)

'So quickly? But why beat about the bush? One-two-three and it's done! What is she doing? Has she gone to bed?' 
In Armenian, the "feline" metaphor is indirectly realised by the verb with the literal meaning 'to mew', which means 'to sing badly in a high-pitched voice'. In English, one identifies badly performed violin music and uses the verb to squeak in its literal sense to refer to it, but this verb is also zoomorphic since it may refer to the squeaking of mice. It is similar to the Russian verb skripet' ('to screech') in the sense that it is used to refer to doors and car brakes. In this way, the instrument in question, violin in English, if shoddily made or amateurishly played, emits a sound similar to that which in Russian gets its name from the word skripka (i.e. 'that which squeaks').

\section{[2.2] Inarticulate speech}

Presently, we examine the other branch of the classification system, to which pertains everything which is connected with speech, even inarticulate speech. It appears that here it is possible to distinguish the following four classes, each of which will be examined in turn:
A. Inarticulate speech (of infants or adults)
B. Approving/disapproving reactions
C. Plurality "speakers"
D. Semiotically meaningful speech

\section{A. Inarticulate speech (of infants or adults)}

Infants cannot pronounce words: their "conversation" resembles more the singing of birds than human speech; hence, we have the Russian verb gulit', and the English to coo with the same meaning, where both verbs describe one of the "pigeon" sounds (cf. see below vorkovanie ('cooing')).

But adults may also speak in such a fashion that it is sometimes difficult to discern what they are saying: their speech can be both unintelligible and incoherent. This effect is engendered by either of the following two mutually exclusive causes: when the speed of the discourse is either too slow or too fast. If the speech is too slow, unsure, having a staccato-like quality, and consequently too disjointed, then it describes a stuttering speaker, as it were, who makes endless pauses or self-corrections (like the Russian verbs bekat' ('to bleat'), ${ }^{6}$ mekat' ('to bleat'), originally of a goat), or un unstructured discourse (like the Russian verb myčat' ('to moo'), originally of a cow). Both types of slow speech correspond to a recognisable situation of a D-student at an oral exam: in Italian, this situation is associated with the bray of a donkey (ragliare).

[6] It is curious that according to our data the Norwegian verb a breke, with the same literal meaning 'to bleat', utilises a completely different acoustic segment: not intermittency but the colour of someone's voice; it denotes an unpleasant male voice. 
However, the feeling of incoherence is also created when the speech, on the other hand, is too rapid, so that one's thoughts fail to take actual shape; they interrupt one another (cf. the Russian onomatopoeic verb taratorit' ('to jabber')). Taratorit' is not zoomorphic but in Russian this verb has a zoomorphic quasi-synonym, strekotat' ('to chirr') (of a grasshopper). The latter describes not only human, more precisely female chatter, but also the sounds made by such artefacts as sewing machines or type writers. In this connection, we can mention the verb treščat' which describes, apart from the sound of breaking wood, the "conversation" of magpies; hence, the verb's applicability to female speech.

On the whole, a similar situation obtains in Crimean Tartar: as in Russian and many other languages, rapid female speech is also coded in this language by specific lexical means. However, such speech is associated with the more traditional artefacts of that culture: in Crimean Tartar, 'to chatter' is rendered by the same verb which also denotes 'clatter', 'shrill sounds of zurna' and 'clicking of the beads on the abacus'.

In English, rapid incoherent speech can be rendered as canine yapping, which according to our informants, is not gender specific, e.g. they were just yapping away the whole night which may be associated with both men and women. Furthermore, in Estonian, we encountered two zoomorphic verbal metaphors of the same kind, which according to our informants are also not gender specific. These are the verbs kaagutama (lit. referring to the clucking of chickens) and prääksuma (lit. 'to quack and metaphorically 'to talk rubbish (especially pertaining to children)). However, we note that in Norwegian cackling (a kakle) is in its metaphorical meaning interpreted as associated only with women: as a 'loud meaningless conversation or laughter'.

Thus, rapid female speech (always pejoratively judged as incoherent, meaningless, etc.) appears to be a significant parameter in the sound domain. Evidently, it is necessary to distinguish female laughter as a separate class in typological questionnaires on this topic. In English, along with the verb to yap, which is unmarked with respect to gender, there is also a metaphor especially associated with the female chatter and laughter: these two activities are coded by the verb to tweet whose literal meaning denotes avian "conversation", something along the lines of the Russian verbs 'ščebetat' ('to chirp'), 'čirikat' ('to twitter').

\section{B. Verbal reactions}

In this section, we examine the examples of verbal inarticulate reactions. Just as non-verbal, verbal reactions are divided into positive and negative, but they do not form a further mixed class since the contrast is sufficiently discrete. As before, the domain of negative, that is, disapproving reactions is developed significantly

[7] It should be pointed out that ščebetat', and to a lesser extent čirikat', may also be applied to female speech but only in a positive way, see below for further discussion. 
more thoroughly, and we start the discussion with the latter.

\section{B1. Disapproving reactions}

Disapproving verbal reactions represent a verbal confrontation to someone else's speech, action, or a situation generally speaking. One can oppose all that to a varying degree, starting with a simple expression of disapproval, to an intense enmity, which may turn into aggression, so that the verbal reactions are scaled and thus subdivided into smaller classes.

\section{B1.1. Weak confrontation}

FYRKAT' ('to snort'). A very weak type of confrontation is described by the Russian verb fyrkat', which in its literal meaning is associated with a brief characteristic sound made by a horse or a dog upon coming out of the water. It is used metaphorically as an expression of refusal or (passive) disapproval, cf. the following example from the RNC:

(2) Podružki peregljanulis', fyrknuli, podkhvatili drug druga pod ruku i pribavili šagu - komu nravitsja byt' ob"ektom rozygryša (Semen Daniljuk, Rublevaja zona)

'The two friends exchanged looks, snorted disapprovingly, took each other under the arm and quickened the pace. Who enjoys falling victim to a practical joke?'

It is important to bear in mind that, even in the metaphorical meaning, the verb in question retains the sound that accompanies it despite the fact that the verb becomes semantically loaded. That is as a rule a special kind of sound, although it is usually accompanied by some form of speech, (cf. from D. Dontsova: Samo ničego ne portitsja - fyrknula Ol'ga ('I only hope nothing gets spoilt - Olga snorted.). Note, however, the unmarked fyrknula i ušla ('she snorted and left') - it is possible that something may have been said disapprovingly, and, on the other hand, it may not have been. In English, there is a direct analogue for this Russian metaphor but its source is different, being namely grunting which, as we have seen, transcends a simple physiological onomatopoeia in Russian.

VEREŠČAT' ('to churr') Furthermore, Russia has its own verb of verbal reaction associated with the sound of a pig, namely, vereščat', although it is possible that this verb, just like vizžat' ('to squeal'), is not entirely zoomorphic. When applied to humans, it may denote a sharp, rumbling sound accompanying an act of passive 
resistance (particularly that of children), which, as a rule, is easily suppressed. ${ }^{8}$ In addition, the confrontation may also be verbal having the same quality of timbre.

VORČAT' ('to grumble'). An ordinary grumbling is a form of passive verbal opposition, and is of a lower register: the speaker has an objection - he does not agree - but his disagreeing is so passive in nature that it is clearly not directed towards the source of displeasure, but towards himself, so to speak. This situation is metaphorically represented in German through the verb brummen, which literally describes the sounds made by a bear, bull or a swarm or bees, something which in itself presents a curious case of contamination. We have already noticed the association of a bull with a bear; therefore it occasions very little surprise. But the association with a swarm of bees is rather interesting. We notice that the sound of a swarm is clearly distinguished from the sound of a single bee, and they belong to the different classes of the zoological metaphor. This is especially evident in the Russian material: a bee buzzes (žužžat') like a small machine such as a spindle or an electrical shaver, but a swarm drones (gudet') like bells or heavy airplanes above the airport. Furthermore, the German verb brummen may also apply to the drone/hum of the airplanes. It is precisely the whole swarm and not a single bee that is amalgamated with a bear and a bull in German. In Armenian, a tom cat grumbles in approximately the same manner, perhaps softer: it does not mew (mewing is phonetically not similar to grumbling); it does not purr (purring is a positive and not a negative reaction). And that what could be termed "to whir" may be applied to humans (cf. with the possible meaning 'to whir from spite' in Armenian). ${ }^{9}$

ŠIPET' ('to hiss'). This is yet another type of a passive reaction. This verb is not directed towards the source of displeasure but towards those individuals in the surrounding environment and not only towards oneself. It is true that this action is performed clandestinely, silently; hence, we have the following type of a zoological metaphor: the hissing of a snake. One (usually a woman as she is less likely to engage in open conflict) hisses from jealousy and malice in many languages, including in the Slavonic and Germanic.

[8] Compare, however, the following example from the RNC:

(i) Vereščit, ručonkami soprotivljaetsja i ne daetsja ni v kakuju, pop s nej izmučilsja, no krestik na nee nadet' tak i ne smog. (Ėduard Volodarskij, Dnevnik ubijcy)

'She is hissing, resisting with her small hands and is not about to give in for anything. The priest was exhausted from fighting her, but he still did not manage to put the little cross on her.'

[9] Compare here with the expression found in the EANC (Eastern Armenian National Corpus) which is literally translated into Russian as ' $\mathrm{i}$ čtoby my vmeste perežili [peremurčali] našu grust" ('so that we may overcome [over-whir] our grief') (www . eanc . net). 
However, Norwegian uses its own resources to express the "hissing" metaphor. The animal used is a type of a polar mouse - a lemming - a rather small, yellowish, almost tailless creature, like a hamster or a ground squirrel, whom Norwegians perceive as being quite angry. From time to time, the lemmings migrate and when they do, hordes of lemmings tend to occupy large spaces. The hissing of lemmings is denoted by the verb a frese, and this verb when applied to humans means that one is feeling angry and this emotion becomes overwhelming, as if one were seething with rage, but one is quite incapable of doing anything about it (cf. a similar metaphorical use of Russian kipet' 'boil'). Evidently, such "undirected" hissing is of a somewhat different type than what we have just described. Furthermore, it is not gender specific, that is, it is not seen as a solely female quality.

And we arrive at the last variety of hissing which we have encountered in our material. It also denotes a type of snake hissing but it has a different semantics, aptly expressed by the English verb to hiss. This verb refers to a feeling of indignation felt by a large group of people, for instance, in a grandstand during a football match or in the theatre. We observe that in Russian this type of situation has its own non-zoomorphic but onomatopoeic means of lexical marking, namely, the verb šikat' ('to boo, hiss'), since hissing is already "reserved" to denote female malice or jealousy.

\section{B1.2. Aggressive confrontation}

Aggressive confrontation could be called, with a certain degree of conventionality, a "canine" reaction because dogs, and to a lesser degree wolves, ${ }^{10}$ serve as the donors of this type of metaphor. In Russian, these are the verbs vjakat' ('to yap'), ogryzat'sja ('to snarl'), and ryčat' ('to bellow'). They describe a confrontational verbal reaction that escalates in its intensity and is openly directed towards the source of displeasure. In English this is expressed by the verbs to growl and to snarl (also implicating the escalation in intensity, cf. I told him we needed to leave and he just GROWLED at me, or If they SNARL at each other they are really fighting. It is evident from these examples that the confrontation is so aggressive that the one who engages in it is wholly capable of emerging from it as a victor. A laconic and vivid interpretation of a pair of Norwegian cognates corresponding to these English quasi-synonyms provided by Tore Nesset may serve as a good illustration. The verbs in question are å knurre (lit. of a dog or a wolf, but not of a bear) and the more aggressive å snerre: "If I suggest that we should do something, and my addressee knurre, that means that he doesn't want to do it, but we'll end up doing it anyway. But if he snerre, then nothing will come of it."

[10] In Italian, according to some of our informants, it is lupine and not canine reactions that are mapped onto human beings, cf. ringhiare - lit. 'to growl (of a wolf)', metaphorically 'to react brusquely (of people)'. 


\section{B2. Approving reactions}

There are very few reactions of this kind. In Russian, we found two in fact: $k r$ jaknut' ('to give a quack'), as a reaction of surprise as well as approval in response to an unexpected action from one's partner, and myčat' ('to moo'), which refers to a both verbal and non-verbal reaction of pleasure (for instance, when one's back is being scratched or when one is eating something delicious). The latter is attested in Bulgarian, muča. Furthermore, the verb grukham is used in Bulgarian as a lexical marker of pleasure with the literal meaning 'to grunt'. It is known that this verb has a metaphorical semantics different from the verb muča. It seems that the meaning is closer to a satisfied growling. In Russian, growling cannot be applied to humans, something which is possible in Estonian, in which the verb mõmimisema literally denotes growling of a satisfied bear.

\section{The plural subject}

The zoological metaphor helps distinguish a class of plural subjects which are important for humans. The conversation of couples that are in love (cf. Russ. vorkovat' ('to coo') - lit. of pigeons) as well as when two people hurl abuse at each other (cf. Russ. lajat'sja ('to yap')) are usually marked in different languages. Furthermore, as we have already examined it in some detail, women who chatter and laugh, and possibly children too (see 2.A above), present an important type of plural subject. Crowd in connection with non-verbal reactions (1.A) was also mentioned as a relevant plural subject. We have already discussed the fact that in the context of such a plural subject, as crowd, the verb revet' ('to roar') (lit. of a bear, lion or bull) is not perceived in the same fashion as in the context of a singular subject. The former denotes an evaluative non-verbal reaction, whereas the latter crying of a child or an aggressive male voice. Moreover, in Russian, the crowd may also galdet' ('to make a racket') like a number of large birds such as jackdaws or crows (cf. the Bulgarian verb gracha, lit. of crows or geese). This is a description of a simultaneous yet incoherent loud speech characteristic of a large number of people. By itself, such speech is neither reactive nor evaluative, in contrast to revet' or to the second example of the zoological metaphor with the plural subject, the English verb hiss (2.B1), but the speaker himself judges it negatively as an unnecessary clamour. Quite another matter is the Russian verb gudet' ('to drone'), literally pertaining to a swarm bees or a beehive (cf. also the English verb to buzz (bee, mosquito)), which also relates to "orderly" noise of the same kind, for instance, when a group of people purposefully discusses an idea. In this situation, the evaluation may also be positive.

When speaking of verbal situations which in a given language may be expressed as animal sounds, in particular as verbal reactions, we can clearly distinguish them from the physiological sounds: it is precisely speech that possesses its own semantics. Relaying on a metaphor, we certainly cannot exactly repro- 
duce what was in fact said, but we do know How it was said, and can therefore infer the contents. Thus it is not only the phonetic form of a sound, intrinsic to a given animal as in the physiological zoological metaphors, that is significant in verbal reactions, but the linguistic form of the animal itself. In other words, the metaphors are not created here simply on the basis of the onomatopoeic effects, but on the basis of more complex semantic considerations.

The following group (2.D) comprises verbs which either use onomatopoeia indirectly or do not have any onomatopoeic associations at all: these are the lexemes which code verbal sign situations present in a given culture by relying on the animal form.

\section{Semiotically significant speech}

A good example of a semiotically meaningful metaphor is the Russian verb zudet' ('to buzz') (lit. of a mosquito) in its metaphorical meaning 'to bother, to nag someone with one and the same advice, request or tale of moral edification'. Čto ty zudiš'! ('Why are you on my case!) may be heard as a response to an insistent request wash the dishes and even to don't procrastinate, do your homework. Such a response will necessarily be crude and impolite but not impossible to make. It is an interesting fact that in Hindi a verb denoting the buzzing of a fly performs the very same function. It is clear that in the given case the metaphor relies on the monotonous sound made by an insect that is intent on capturing its prey and is perceived as an irritating but minor nuisance.

We also note that a similar verb in Italian - ronzare (pertaining to mosquitoes, flies, and bees) - evolves in a completely different fashion. Its acoustic component in the recipient domain is made wholly subordinate to the idea of a purposive circular motion, which is associated with all these insects. This verb undergoes not a metaphoric but a metonymic shift and, as a result, it means 'to hang around a girl'.

The meaning of the Russian verb brekhat' ('to yap') is also quite removed from the onomatopoeia: it does not bring to mind the canine barking. However, the origin of this metaphor is clear: it comes from the idea of "empty" barking, barking without a reason, which erroneously informs the owner of the danger. A very similar idea is present in the Bulgarian verb laja which is used particularly in the situation when the politicians talk a lot and without making much sense.

The semantics of mapping of both the English verb cackle to mean 'to care for someone (with a touch of excessiveness) and the Bulgarian kudkudjakam to mean 'to find oneself in a panic (of women)' can be traced to the image of a stupid and restive brooding hen. It is also probably possible to explain the origin of the German metaphor associated with the word kollern ('cry of a turkey'), namely, 'to speak angrily', in that it refers to the "angry" facial expression of an important person. But why is 'to neigh' (of horses) in Hindi when applied to humans under- 
stood as 'to speak with false enthusiasm' (cf. Russ. veščat' ('to prophesy, broadcast'))? Or why does the Russian verb karkat' ('to croak') (of crows), but Armenian 'to croak (of frogs)', mean 'to predict bad development of events in the "human" domain when in Hindi the verb 'croak' is significantly closer to an onomatopoeia: the monotonous repetition of a crow's cry means 'to repeat the same thing' when associated with human speech.

\section{[3] A LitTLE BIT MORE LINGUISTICS}

It seems that the task of building a typology of such "weather-beaten", semiotically saturated recipient meanings will not be a simple matter because here it is difficult to compare the lexemes from different languages, but perhaps the number of such unadulterated cases may not be very high in the end. However, there is a different, no less serious danger with regard to the development of such a typology: the illusion of a facile juxtaposition of lexemes. Let us take, for instance, the English verb to bark, which is easily and correctly translated into Russian by the verb lajat' because both of these verbs presuppose one and the same type of subject (dog) and, generally speaking, imply one and the same sound. It is clear that not every English expression with bark will be translated as lajat' and vice versa ${ }^{11}$, but, on the whole, this should not interfere with their comparability.

However, casting a more attentive glance at these verbs should raise some questions. In particular, it seems that the metaphorical verb to bark is naturally used with the collocation to bark commands ('to issue military orders in a brusque, especially shrill, tone of voice'). But such a mapping is impossible in Russian: in this case, one would rather say rjavkat' ('to bellow, bawl') and not *lajat' owning to wholly linguistic reasons. The point is that the Russian verb lajat' can only be interpreted iteratively and it simply cannot describe a single act of barking (a single bark, as it were), whereas the English bark is clearly more neutral in this respect.

Most probably, the parameter 'singular : iterative', as well as 'discrete : nondiscrete', should be regarded as relevant, albeit to a lesser degree than the type of subject.

And incidentally, there is one more interesting question: how is the quantum of sound specified in different languages? Indeed, it is well known that the quantum of food stuffs is lexically coded, e.g. Russ. ne s"el ni kroški ('he didn't eat a crumb'), as well as the quantum of liquids, e.g. Russ. ne popil ni kapli ('he didn't drink a drop'). According to all traditional theories of metaphor, emotions may

[11] For instance, in English, there is a phase you're barking up the wrong tree which conjures up a hunting scene in which a dog is chasing a cat: the cat is sitting in the tree while the dog is barking at it. Here the dog is barking at the "wrong" tree - the one without a cat. Consequently, the meaning that emerges is 'you're swearing in vain', that is, more literally 'that's not the person to be barking at'. Of course, this meaning is not to be directly found in Russian. See Dobrovol'skij \& E. (2005) on the theoretical aspects of the culturally conditioned specificity of phrasal metaphors. 
be equated with liquids because the quanta of liquids are suitable to emotions, e.g. compare ne boyalsja/ne ljubil ni kapli (lit. he wasn't afraid/didn't love (her) one single drop). And what about the sounds? We usually say: On ne izdal ni zvuka (He didn't utter a sound) - but what sound? How is such a sound to be marked lexically? What is it compared to, if this is a metaphor? In such cases, one usually says in Russian, ne piknul (he didn't make a peep), if the person in question was ordered to do something, and although he did not agree with it, he did not remonstrate against it either. ${ }^{12}$

This is not an instance of a zoological metaphor. In contemporary Russian, the verb pikat', when in the imperfective aspect and having an iterative semantics, is more strongly connected to the artefactual instruments, such as radios, telephones, etc., and their electronic "peeping" sound, cf. an example from the RNC:

(3) telefon u nego pikaet každye pjat' minut (Andrej Belozerov, Čajka) 'his telephone keeps beeping every five minutes'

In English, the quantum of sound is zoomorphic: it corresponds to a single peep of a chick, e.g. she didn't make a peep. In Norwegian, on the other hand, it is a single duck "quack", e.g. han sa ikke et kvekk 'he didn't say a word' (lit. 'didn't say a quack').

\section{[4] CONCLUSION}

We have already mentioned that the present paper does not lay claim to comprehensiveness and completeness. Its task was merely to draw the attention to lexical typology, in particular to the problem regarding the construction of a typology of sound verbs. Is this task realisable in the domain of the zoological metaphor, for instance?

Our material shows that:

- the same sounds are categorised differently in different languages (in particular with regard to the opposition iterativity vs. singularity)

- the amalgamation of sounds ("human", "animal" and "artefactual") happens differently in different languages

These facts, at first sight, hinder the development of some universal system in the lexicon. At the same time, we have seen on the basis of the examined linguistic material that:

[12] Cf. from the RNC:

(i) A Strekalovykh tak pripugnem, čto piknut' ne posmejut (Leonid Juzefovič, Kostjum Arlekina) 'But I'll scare the Strekalovs so much that they won't dare to make a sound.' 
- the same significant sound situations and their parameters are lexically distinguished in different languages, and they are expressly coded by lexical means, often zoomorphically, but sometimes also by their own verbs of sound or ordinary verbs

- it is clear that such situations and parameters are relevant for humans and are independent of a particular language and culture. It would be possible to say that they are universal (and that, of course, needs to be shown), or, at the very least, that they lay claim to universality.

In all probability, a typology of a linguistic domain that is developed in this way must be possible - shall we try and develop it?

ACKNOWLEDGMENTS

This work is supported by a grant from the RFFI (09-06-00364-a).

\section{REFERENCES}

Bonč-Osmolovskaja, A. A., E. V. Rakhilina \& T. I. Reznikova. 2009. Conceptualization of Pain: a Database for Lexical Typology. In P. Bosch, D. Gabelaia \& J. Lang (eds.), Logic, language, and computation, 110-123. Heidelberg: Springer.

Bricyn, V. M. \& E. V. Rakhilina. 2009. Koncept bol'v tipologičeskom osveščenii. Kiev: Dm.Buraho Publishing House.

Comrie, B. 1976. Aspect: An introduction to the study of verbal aspect and related problems. Cambridge: Cambridge U. Press. (rev. ed. 1981).

Dahl, Ö. 1985. Tense and aspect systems. Oxford: Blackwell.

Dobrovol'skij, D. \& Piirainen E. 2005. Figurative languages. Amsterdam: Crosscultural and cross-linguistic perspectives.

Dybo, A. V. 1996. Semantičeskaja rekonstrukcija v altajskoj ètimologii. Moscow.

Goddard, C. \& A. Wierzbicka. 2002. Meaning and universal grammar: Theory and empirical findings. Amsterdam: Benjamins.

Kholodovič, A. A. 1969. Tipologija kauzativnykh konstrukcij. Leningrad: Nauka.

Koptjevskaja-Tamm, M. 2009. Approaching Lexical typology. In M. Vanhove (ed.), From polysemy to semantic change: Towards a typology of lexical semantic associations., Amsterdam and Philadelphia: Benjamins.

Koptjevskaja-Tamm, M., M. Vanhove \& P. Koch. 2007. Typological approaches to lexical semantics. Linguistic Typology 11(1). 159-186. 
Majid, A., J. S. Boster \& M. Bowerman. 2008. The cross-linguistic categorization of everyday events: A study of cutting and breaking. Cognition 109(2). 235-250.

Majid, A. \& M. Bowerman. 2007. Cutting and breaking events: A crosslinguistic perspective. Cognitive Linguistics 18(2).

Majsak, T.A. 2007. Aquamotion - glagoly dviženija $v$ vode: leksičeskaja tipologija. Moscow: IndrikBri.

Newman, J. 1997. The linguistics of Giving. Amsterdam, Benjamins.

Newman, J. 2002. The Linguistics of Sitting, Standing, and Lying. Amsterdam: Benjamins.

Newman, J. 2009. The linguistics of eating and drinking. In Studies in typological linguistics, vol. 84, Amsterdam and Philadelphia: John Benjamins.

Stojnova, N. A. 2008. Glagoly zvučanija v russkom jazyke. Moscow State University MA thesis.

Viberg, A. 2002. The verbs of perception. In Oesterreicher W. Haspelmath M., König E. \& W. Raible (eds.), Language typology and language universals, Berlin: De Gruyter. An International Handbook.

Zaliznjak, A.A. 2001. Semantičeskaja derivacija v sinkhronii i diakhronii. Voprosy jazykoznanija 2. 13-25.

Zaliznjak, A.A. 2009. Catalogue of Semantic Shifts: towards a Typology of Semantic Derivation. In M. Vanhove (ed.), Towards a Typology of Lexical Semantic Associations, Paris: Mouton de Gruyter.

AUTHOR CONTACT INFORMATION

Ekaterina Rakhilina

Russian State University for the Humanities

Moscow, Russia

rakhilina@gmail.com 